\title{
Symbolika nominacji ludzi \\ za pomocą rzeczownika baran \\ - wpływ religii na kształtowanie się personifikowanego znaczenia apelatywu
}

Przenoszenie na ludzi nazw zwierząt ma wielowiekową tradycję, zarówno w piśmiennictwie świeckim, jak i religijnym. Funkcjonuje zresztą, może jeszcze w znacznie szerszym wymiarze, i na gruncie języka mówionego, w jego potocznej odmianie. Jednym $z$ impulsów dla owego procesu, a istotnym dla rozważań przedstawionych w artykule, jest antropomorfistyczne przypisywanie zespołu cech danemu zwierzęciu, np.: sowa - mądrość, lis - przebiegłość, lew - majestat, mrówka - pracowitość. Oczywiście wskazane uschematyzowane przenoszenie na zwierzęta konkretnych cech ludzkich nie ma charakteru ścisłego i niezmiennego. W danym okresie historycznym i dla określonej grupy użytkowników języka ma ono zwykle charakter jak najbardziej jednoznaczny, niebudzący wątpliwości. Na przestrzeni wieków widać jednak, iż alegoryczne obrazowanie może ulec przeobrażeniom i z czasem zyskiwać nowe skonwencjonalizowane cechy. Podobnie rzecz się ma z nominacją ludzi za pomocą nazw zwierząt, zwłaszcza wtedy gdy u jej podstaw leży wtórne przypisanie człowiekowi wybranych cech ludzkich, uprzednio skonkretyzowanych dla poszczególnych zwierząt. Ma ona charakter zbliżony do zabiegu antonomazji, ale również tylko w odniesieniu dla danego okresu, a także konkretnego kręgu kulturowego, grupy społecznej bądź religijnej itp. ${ }^{1}$

1 Wskazany problem porusza wiele publikacji; zob. np. Pajdzińska (1990), Martuszewska, red. (1993), Kobielus (2002), Nowakowska (2003) oraz inne, przedstawione w wykazie literatury, przykładowo wybrane opracowania. 
Postać barana już od najdawniejszych czasów jest szeroko wykorzystywana w symbolice religijnej. Był np. emblemem egipskiego bóstwa, Amona-Ra, fenickiego Baala czy babilońskiego Ea-Oannesa, w symbolice hinduskiej to Parabrahman, czyli niezróżnicowana całość, centrum kosmicznych energii ${ }^{2}$. W mitologii greckiej skrzydlaty baran o złotym runie przeniósł w powietrzu Fryksosa do Kolchidy, co uratowało młodzieńcowi życie zagrożone zdradą zazdrosnej Ino. W podzięce za ocalenie Fryksos złożył Zeusowi owego barana w ofierze, a złote runo podarował królowi Kolchidy. Bóg umieścił następnie barana na niebie jako gwiazdozbiór Aries ${ }^{3}$.

Baran, postrzegany już w starożytności jako zwierzę ofiarne ${ }^{4}$, również w Piśmie św. występuje przede wszystkim w takim kontekście, choć symbolika nie jest tu jednokierunkowa. Generalnie w Starym Testamencie była ona mało rozwinięta, a dotyczyła przede wszystkim święta Paschy, kiedy jednoroczne, wolne od skazy zwierzę uroczyście zabijano i spożywano. Baran często występował jako ofiara za grzechy, dziękczynna i biesiadna. W tekstach XVI-wiecznych ów motyw pojawia się nie tylko w katolickich i innowierczych tłumaczeniach Biblii, ale także w nawiązujących do niej utworach świeckich:

$K$ temu jeszcze będziecie ofiarować kozła jednego za grzech i dwa barany łońszczaki ${ }^{5}$ za ofiare spokojna (BibRadz Lev 23/19).

I zarzeże barana na miejscu, gdzie rzeżą ofiarę za grzech i na całopalenie (BudBib Lev 14/3).

pomażecie podwoje oba u drzwi i z wirzchu w domiech swoich, gdzie będziecie jeść barana onej nocy (BielKron 30).

Iz dałcibych ja tobie, miły Panie, wiele wołów i baranów za występki swoje (RejPos 119v).

Dopiero w Nowym Testamencie mamy do czynienia $\mathrm{z}$ innego typu nominacją. Tu rzeczownik baran zaczyna nazywać również ludzi. W tym miejscu warto zwrócić uwagę na dwukierunkowość owej ewolucji: apelatyw może

2 Zob. Cooper (1998, s.v. baran), Cirlot (2000, s.v. baran), Kobielus (2002, s.v. baran).

${ }^{3}$ Por. XVI-wieczny fragment: Ale Frixus cało przeszedt do Kolchis króla Oety, tam barana Marsowi ofiarowat (BielKron 54).

Wszystkie fragmenty z tekstów w transkrypcji autorki. Ponieważ cytaty pełnią tu wyłącznie funkcję ilustracyjną dla rozważanych kwestii, unormowano pisownię wielkich liter oraz zastosowano współczesną interpunkcję w celu uniknięcia niejasności; uwagi lub uzupełnienia cytatów podane w nawiasie kwadratowym, skróty źródłowe użyte zwykle za SpXVI (rozwiązane na końcu artykułu).

${ }^{4}$ Baran był zwierzęciem ofiarnym m.in. dla wyznawców islamu i w kulturach starożytnych, greckiej, celtyckiej, galijskiej. Zob. Cooper (1998, s.v. baran).

5 łońszczak 'zwierzę urodzone zeszłego roku'. 
odnosić się do grupy ludzi, ale także stanowić symboliczną nazwę jednostkową - Chrystusa Odkupiciela. Owo rozróżnienie w polskich tekstach będzie miało swoje odzwierciedlenie w repartycji formy podstawowej wyrazu i formacji deminutywnej.

Forma podstawowa poświadczona jest już w okresie staropolskim, lecz odnosi się wyłącznie do zwierzęcia, jako nazwa Chrystusa pojawia się jedynie deminutivum baranek (SsU). U progu doby średniopolskiej mamy już natomiast liczne wystąpienia rzeczownika baran w odniesieniu do Chrystusa. W XVI wieku używano w tym znaczeniu zarówno rzeczownika neutralnego, jak i deminutywnego, przy czym ten pierwszy charakterystyczny był wyłącznie dla tekstów innowierczych, drugi - również dla katolickich ${ }^{6}$. Wyraz baran trzykrotnie wystąpił w odautorskich fragmentach tłumaczeń Nowego Testamentu - w uwadze marginesowej u Stanisława Murzynowskiego i we wstępie u Szymona Budnego:

Tak i w Objawieniu one słowa fałszuje [Beza]: Bóg wszechmocny kościołem jej (rozumiej Jerozolimy) i baran. Bo tak po łacinie przełożyl: Bóg wszechmocny kościołem jej jest, to jest baran (BudNT c2v).

Znacznie częściej używany był jednak w tekstach polemicznych, np.:

czym śmierdzi katolika rzymska przed majestatem Pana zastępów i przed Baranem Bożym (CzechEp 27).

Także w Nowym Testamencie Chrystusa Jan [...] [zowie] Baranem (CzechRozm 266). Tu na tym miejscu Piotr ś. przypomina człowieka Chrystusa Pana: Barana za nas ofiarowanego i zabitego (NiemObr 119).

Ciekawy pod względem współwystępowania obu form, a także dwu omawianych kręgów znaczeniowych jest fragment Katechizmu Marcina Białobrzeskiego:

Otóż masz baranka twego Mesjasza, aby barana zgładził, którego pierwej ofiarowano, a potym jedziono [= jedzono] (BiałKat 346),

w którym odnajdziemy oczywiste nawiązanie do Ewangelii wg św. Jana, gdzie - w odróżnieniu od Ewangelii synoptycznych - przedstawiono śmierć Jezusa następującą w chwili zarzynania w świątyni baranka paschalnego.

Przytoczone powyżej cytaty wskazują na rozciągnięcie na nominowaną nazwą zwierzęcia osobę Chrystusa szeroko rozumianego pojęcia ofiary ${ }^{7}$, przy

${ }^{6}$ Por. np.: I leżeć będzie na sienie [= sianie] baranek upokorzony (PatKaz II 57v); Toć jest ono święte miasto [...] a oblubienica baranka onego, który gładzi grzechy świata (KromRozm II t).

7 Określenie Chrystusa mianem Baranek Boży ma wielowarstwową i nie do końca jasną podstawę. Zwykle wiąże się je z pojęciem ofiary - z jednej strony ze śmiercią krzyżową stanowiącą ofiarę za ludzkie grzechy, z drugiej - z całym jego, nieskalanym grzechem, życiem 
czym warto zwrócić uwagę, iż w omawianym okresie według danych SpXVI określenie Baran Boży (zob. wyżej: CzechEp 27) pojawiło się tylko raz, natomiast wyrażenie $\mathrm{z}$ formą deminutywną 53 razy, np.:

$z$ tej [panny] się urodzi Baranek Boży niepomazany, zbawiajac wszytki (BielKron 19). Baranku Boży, który gładzisz grzechy świata, zmiłuj się nad nami (KrowObr 69v).

Po XVI wieku nie spotyka się już w tekstach użyć formy baran w odniesieniu do Chrystusa, jej miejsce całkowicie wyparła forma deminutywna baranek ${ }^{8}$. Wśród cytatów zamieszczonych w LSjp, które obejmują XVI - XVIII wiek, żaden nie jest już użyty jako symboliczny ekwiwalent dla proprium Chrystus, podobnie w młodszym Sw oraz współczesnych SjpD i Swjp. Wszystkie natomiast wymienione słowniki rejestrują omawiane znaczenie dla formacji baranek.

Sięgając do Biblii, zauważymy, iż w Vulgacie odpowiednikiem obu omawianych wyrazów, użytych jako symboliczna nazwa Chrystusa Odkupiciela, będzie forma agnus, podobnie jak zdrobniała forma grecka arnion, która szczególnie często (i bezwyjątkowo) wystąpiła w Apokalipsie.

Drugi ze wskazanych wcześniej - mających swe źródło w Nowym Testamencie - kierunków nominacji człowieka rzeczownikiem baran ma znacznie szerszy zakres, nie odnosi się do Chrystusa, lecz w sensie ogólnym i zwykle formalnie w pl: do ludzi, wyznawców Chrystusa. Tu analiza tekstów wskazuje na ciekawą ewolucję semantyczną, często powiązaną ze sferą emocjonalną, ale $\mathrm{w}$ początkowej fazie przede wszystkim $\mathrm{z}$ kształtowaniem się i transformacją poglądów natury religijnej.

SpXVI odnotował rzeczownik baran również jako nazwę zwierzchnika religijnego, co zapewne ewoluowało z jednej strony z omówionego wcześniej konkretnego znaczenia wyrazu: Chrystus jako zwierzchnik, z drugiej - mogło nawiązywać do wyobrażenia barana, przewodnika stada:

oraz świętym posłannictwem. Pojawiło się ono w Ewangelii wg św. Jana (1/36) w ustach Jana Chrzciciela, gdzie można doszukać się jeszcze innych powiązań interpretacyjnych. Ponieważ użyty przez niego termin aramejski talija nie jest jednoznaczny - tłumaczy się go jako 'baran', ale także 'sługa' - znaczenie określenia Baranek Boży może mieć znacznie szerszą podstawę symboliczną niż samo pojęcie ofiary. Rozbudowany opis tego problemu zob. EkG s.v. baran.

${ }^{8}$ Wśród licznych wyobrażeń zwierzęcych symbolizujących Chrystusa Jolanta Szarlej (2003, 43-44) wspomina również barana, używając jednak wyłącznie formy zdrobniałej, bez jakichkolwiek odwołań do formy podstawowej, co wynika z silnego ugruntowania w języku, sięgającego początków XVII wieku, ograniczenia w dystrybucji obu rzeczowników w omawianym - wtórnie proprialnym - znaczeniu. O jednej z przyczyn tego obrazowania autorka pisze: „Zachowanie tego bezbronnego i łagodnego zwierzęcia najpełniej oddaje charakter Chrystusa - pokorę, poddanie się woli Boga" (Szarlej 2003, 43). 
i polecił mu [Chrystus Piotrowi] przełożeństwo nad wszytkimi owcami, to jest nad ludem wszytkim wiernym, i nad barany, to jest nad wszytkimi przełożonymi ich (SkarJedn 63).

Ponadto warto w tym miejscu odwołać się do ikonografii, w której przedstawienie baranka symbolizuje nie tylko Chrystusa ${ }^{9}$ oraz wiernych, ale także postaci ze Starego Testamentu w scenach typologicznych ofiary (Abrahama, Aarona, Melchizedeka, Izaaka) lub alegoriach ${ }^{10}$, bywa też atrybutem wielu świętych, m.in. Jana Chrzciciela i Agnieszki. W XVI-wiecznych polemicznych pismach protestanckich baranek również jest symbolem świętych Kościoła katolickiego, w tym wypadku jednak w kontekstach mających zdecydowanie pejoratywny wydźwięk:

ani go [Chrystusa] też takowi chwala, którzy nie samego tylko chwala, nie w samym obrony szukaja, ale też insze baranki sobie zmyślaja i insze baranki chwala, którym obronę i zwycięstwo przypisuja (KrowObr 69).

Odrzućcie fałszywe baranki i Antykrysta Rzymskiego [tj. papieża] nauki (KrowObr 70).

Generalnie jednak w okresie tym zaczyna już dominować znaczenie mocno ugruntowane w symbolice nowotestamentowej - jako ludu bożego w ogóle, wiernych, jak bowiem podaje EkG (s.v. baranek): „obraz baranka służy do podkreślenia niektórych cech chrześcijanina [...], a stado baranków jest ulubionym przez Chrystusa obrazem Ludu Bożego". Ciekawy natomiast pozostaje fakt podobnego rozgraniczenia form: podstawowej i deminutywnej oraz ścisłe powiązanie ich użycia z konkretnymi tekstami, o jakim wspomniano wyżej. O ile rzeczownik baran w odniesieniu do Chrystusa pojawił się wyłącznie w literaturze polskich reformatorów, o tyle baran jako 'wyznawca religii chrześcijańskiej' (w tym również przedstawione powyżej ograniczenie ‘zwierzchnik grupy wyznawców’) wystąpił jedynie w katolickich polemicznych pismach religijnych, np.:

któremu [św. Piotrowi] pan Krystus klucze królestwa niebieskiego dał, i owce i barany swoje paść i rzadzić kazał (KromRozm I E4).

Tedy mu [św. Piotrowi] Pan zlecił urząd i uczynił go przełożonym Papieżem, Ojcem ojców, Pasterzem, Namiestnikiem swoim, mówiąc po trzykroć: Paśowce i barany moje (SkarŻyw 599).

9 W oficjalnej sztuce dworskiej zaprzestano przedstawiania Chrystusa pod postacią baranka na skutek zakazu wydanego przez synod trulański (691 r.). Zob. EkG s.v. baranek.

${ }_{10} \mathrm{~W}$ Rawennie znajdują się zdobienia, na których przedstawiono pod postaciami baranków apostołów oraz św. Pawła, w katakumbach św. Pretekstata w Rzymie - malowidło z alegorią Zuzanny kuszonej przez starców, gdzie Zuzanna wyobrażona jest jako baranek pomiędzy dwoma wilkami. Zob. ibidem. 
$\mathrm{W}$ tym samym znaczeniu użyto $\mathrm{w}$ tekstach $\mathrm{z}$ XVI wieku również formacji baranek, np.:

Zamykacie ludziom Królestwo Niebieskie, [....] gdy matce waszej (kościołowi rzymskiemu) plujecie w twarz, [...] i jej baranki od niej dzielicie i wyklinacie (SkarJedn 372).

Pasce agnos meos: to jest, sprawuj, rządź, sądź kożdego, żadnego nie wyjmując człowieka, który się kolwiek mianuje być barankiem, to jest wiernym moim (OrzQuin S3v).

Deminutivum - podobnie jak w omawianym wcześniej znaczeniu 'Chrystus' - również i w znaczeniu 'wyznawca Chrystusa', nie było chyba przypisane wyraźnie do tekstów konkretnej doktryny religijnej, skoro pojawiło się również w kontrowersyjnym tłumaczeniu Nowego Testamentu autorstwa arianina:

mówi Szymonowi Piotrowi Jezus: Szymonie Joanów miłujesz(li) mię więcej niż ci? mówi mu: tak, Panie, ty wiesz, iż cię miłuję. Mówi mu: paśbaranki moje (BudNT Ioann 21/15-16).

Jeśli chodzi o dalsze życie w polszczyźnie wyrazów baran i baranek w powyższym znaczeniu, jest ono paralelne do tego, jakie omówione zostało wcześniej - przy wskazywaniu na postać Chrystusa: po XVI wieku na nazwanie wiernych używa się już wyłącznie formacji deminutywnej (zob. LSjp, Sw, SjpD, Swjp). XVII-wieczne analogiczne wystąpienia formy podstawowej wskazują już na ustępowanie $\mathrm{z}$ języka powyższego znaczenia, skoro użyto apelatywu z zabarwieniem ironicznym ${ }^{11}$ lub w znaczeniu zupełnie przeciwstawnym i z nacechowaniem ujemnym, jak w kazaniu ówczesnego duchownego katolickiego:

Iż powiedziano Piotrowi ś.: Pasce Agnos, pasce oves, tedy nie tylko do łodzi, kościoła Chrystusowego [...] zabrał Żydy, jako owieczki wybrane [...], ale też wprowadzit i barany, to jest pogańskie narody. (StarKaz 120).

Właśnie ze znaczenia 'wyznawca religii chrześcijańskiej' ewoluowało następnie znaczenie o znacznie szerszej dystrybucji - osoba nominowana omawianą nazwą zwierzęcą posiadała wszelkie pozytywne cechy chrześcijanina, jednak przestała być postrzegana wyłącznie przez pryzmat religii. Był to człowiek w ogóle cnotliwy i sprawiedliwy, też: pokorny, niewinny, prosty, jak również: bezbronny, słaby, bez owej wcześniejszej dominanty znaczeniowej: 'wyznawca Chrystusa'. W takim właśnie znaczeniu w tekstach z XVI wieku występowała zarówno forma baran, jak i baranek, np.:

11 Wyraz pojawił się w kontrreformacyjnej satyrze, liście do wyższego duchownego, w którym autor donosi o bijatyce w zborze podczas niedzielnego nabożeństwa: Waszej wieltebności stuga i baran Matyjasz Doliwski, kantor zboru ewanjelickiego (DolBitKontr 311). Zob. SjpXVII. 
Gdyby na wojnie dark jeden drugiego, lecz barana dra wszędy niewinnego. (RejZwierc 228v).

[marg] Oznajmuje [Pan] iż mocą Ducha Świętego tak będą skróceni ludzie okrutni, że się nad żadnym srożyć nie będą. [-] wilk i baran społu się paść będa (BibRadz Is 65/25).

Dziwna rzeka Pismo Ś., mówi Ś. Grzegorz, i tak miałka, iż wiej baranek - to jest prosty i nieuczony - brodzić, $i$ wielbład w niej - to jest uczony i doktor - plywać i zatopić się (pyszny heretyk) może. (SkarŻyw 47).

Jak widać, teksty początków doby średniopolskiej pokazują dość wyraźnie, iż obie formy, zarówno baran, jak i baranek w nominacji osób były nazwami generalnie waloryzującymi, co zdecydowanie kłóci się ze współczesnym rozumieniem obu symboli. Mało tego, SpXVI w odniesieniu do pozytywnie ocenianego człowieka notuje nawet więcej - bo 17 - użyć rzeczownika baran niż użyć formacji baranek - jedynie 4. W tym okresie pojawia się jednak także pierwsze zastosowanie nominacji zwierzęcej człowieka o charakterze pejoratywizującym:

Do wszeteczników: [...] A lepiej snadź byście się byli nie rodzili, widząc ony radości, coście je stracili, i coście się z tym światem a z czartem bracili. Nie śmiech to, baranie (RejZwierc 273).

Fakt tak wywrotowego - jak na owe czasy - zastosowania ugruntowanego już przecież silnie symbolu wydaje się mieć swoje źródło w bezkompromisowości oraz radykalizmie autora. Z jednaj strony Mikołaj Rej - jako kalwinista - buntował się przeciwko schematom katolickiej symboliki, z drugiej, nie zważając na zakorzenione w literaturze wzorce, mógł oddać w tym miejscu kiełkującą w polszczyźnie nieoficjalnej, plebejskiej inną ścieżkę rozwoju personifikowanego użycia badanego apelatywu: w znaczeniu 'głupiec'. Począwszy od Sw dla rzeczownika baran będzie to stała w leksykografii eksplikacja o charakterze metaforycznym, wypierająca bez śladu znaczenia waloryzujące. Pojawia się również w SjpD ${ }^{12}$ oraz w Swjp, który - oprócz osobowego znaczenia 'pogardliwie o człowieku głupim, nierozgarniętym, tępym; idiota, tuman'13 - wymienia również: 'osoba urodzona pod znakiem Barana'.

12 SjpD ilustruje to znaczenie cytatem z Prusa: Ach! jakiż ze mnie baran, żem numeru nie zauważyt!

${ }^{13}$ Egzemplifikacja tego znaczenia: Uczyć baranów, w której zastosowano końcówkę fleksyjną A pl charakterystyczną dla rzeczowników osobowych, oraz klasyfikacja hasła jako męskoosobowe w odróżnieniu od apelatywu zwierzęcego (klasyfikacja: męskożywotne) wyraźnie wskazują na silne zakorzenienie we współczesnym języku znaczenia osobowego, teraz już wyłącznie $\mathrm{z}$ dużym ujemnym nacechowaniem. 
Zupełnie inną drogą poszła ewolucja rzeczownika baranek. W XVI wieku był on synonimem wyrazu baran w znaczeniu 'człowiek cnotliwy...', zwykle zresztą z zatarciem funkcji deminutywnej, jednak na przestrzeni wieków, kiedy rzeczownik baran zyskał miano obelgi, formacja ta nadal utrzymała znaczenie, które można uznać za pozytywne. Sw nie wskazuje co prawda owego przenośnego znaczenia osobowego, ale potwierdza je w jednym z przedstawionych przykładów tekstowych: Jaki mi baranek! (= trusia, niewiniątko), SjpD i Swjp notują: 'o człowieku łagodnym, pokornym, potulnym'. To znaczenie zresztą utrwalone zostało w popularnym porównaniu: potulny jak baranek.

I to właśnie przysłowia będą po XVI wieku głównym medium, dzięki któremu przetrwały niektóre dawne znaczenia obu rzeczowników. LSjp cytuje np. XVII-wieczne użycie: Baran beczy, a wilk drze, co następnie objaśnia: „i płacz przeciw możniejszemu nie pomoże”, a Nkpp (s.v. baran 10) przedstawia zbliżony uogólniony zwrot przysłowiowy barana drzeć wraz z ilustracjami tekstowymi od XVI do końca XIX wieku i eksplikacją: 'ciągnąć nadmierne zyski'. Znajdziemy tu również inne tego typu paremia, jak: Mówiwszy po baranie, trzeba też co i po wilku rzec ${ }^{14}$, Na postawie baranek, ale lis (wilk) na myśli (XVI-XIX w.), Barankiem się czyni, a tryksa jak kozieł (XIX w.), Wszedt jako baranek, a zaraz jak lew ryczeć zaczął (XVII-XIX w.), Znać barana między sobolami (XIX w.; tzn. „znać chudopachołka wśród magnatów”). Jak widać, wszystkie przedstawione przysłowia w oczywisty sposób oddalone są już od religijnego pierwiastka znaczeniowego, w wielu dopatrzyć się można także wysuwania się na plan pierwszy współwystępującego komponentu semantycznego: 'człowiek łatwowierny, naiwny' bądź: 'człowiek ubogi', w sensie uogólnionym: 'człowiek nisko postawiony w hierarchii'.

Wskazane fragmenty tekstów z początków doby średniopolskiej uzmysławiają, jak wielką ewolucję w języku przeszedł apelatyw baran w znaczeniu osobowym - od użyć w zakresach typowo waloryzujących do wyraźnie negatywnych w polszczyźnie współczesnej. Znaczącym elementem w pragmatycznym ujęciu rzeczownika w omawianej funkcji był pierwiastek religijny. Takie niejednoznaczne, uzależnione od wielu czynników postrzeganie człowieka nominowanego apelatywem będącym nazwą zwierzęcia ma w historii języka

${ }^{14}$ Nkpp (s.v. baran 29, wilk 49) wymienia liczne warianty tego przysłowia, również wersji odwróconej, np.: Rzekszy po wilku, czemuż po baranie nie rzec? Przedstawione cytaty pochodzą z tekstów z XVII-XIX wieku oraz Sw. Przy kolejnych odwołaniach do przytoczeń z Nkpp umieszczone przy słowie lub wyrażeniu przysłowiowym przedziały czasowe odnoszą się do cytowań zawartych w księdze. 
długą i bogatą tradycję. Nierzadko też ważnym bodźcem do ugruntowania się $\mathrm{w}$ danej epoce jakiegoś symbolu był właśnie wpływ religii ${ }^{15}$.

\section{Literatura}

Cirlot J. E., 2000, Słownik symboli, przekł. I. Kania, Kraków.

Cooper J. C., 1998, Zwierzęta symboliczne i mityczne, przekł. A. Kozłowska-Ryś, L. Ryś, Poznań.

Forstner D., 2001, Świat symboliki chrześcijańskiej, przekł. i oprac. W. Zakrzewska, P. Pachciarek, R. Turzyński, Warszawa.

Kobielus S., 2002, Bestiarium chrześcijańskie, Warszawa.

Martuszewska A., red., 1993, Literacka symbolika zwierząt, Gdańsk.

Nowakowska A., 2003, Człowiek jak zwierzę. Sfrazeologizowane porównania doczasownikowe na podstawie Słownika frazeologicznego języka polskiego, „Język a Kultura”, t. 15: Opozycja homo - animal w języku i kulturze, red. A. Dą browska, Wrocław, s. 97-102.

Pajdzińska A, 1990, Antropocentryzm frazeologii potocznej, „Etnolingwistyka” 3, s. 59-68.

Raszewska-Żu rek B., 2010, Ewolucja niektórych elementów stereotypu psa w polszczyźnie, „Studia z Filologii Polskiej i Słowiańskiej” 45, s. 65-80.

Solik R., 2003, Motywy zoomorficzne w kulturze artystycznej średniowiecza. Rekonesans, „Język a Kultura”, t. 15: Opozycja homo - animal w języku i kulturze, red. A. Dąbrowska, Wrocław, s. 63-80.

Szarlej J., 2003, Biblijne epifanie zwierzęce na tle opozycji homo - animal, „Język a Kultura”, t. 15: Opozycja homo - animal w języku i kulturze, red. A. Dąbrowska, Wrocław, s. 33-48.

Wys oczański W., 2003, Opozycja homo - animal z perspektywy reguł postępowania (na materiale frazemów wybranych języków), „Język a Kultura”, t. 15: Opozycja homo - animal w języku i kulturze, red. A. Dąbrowska, Wrocław, s. 81-96.

Zimnowoda J., 2003, Opozycja homo - animal w ekspresywnych zwrotach językowych, „Język a Kultura”, t. 15: Opozycja homo - animal w języku i kulturze, red. A. Dąbrowska, Wrocław, s. 103-115.

\section{Skróty źródeł}

EkG - Gryglewicz F., Łukaszyk R., Sułowski Z., red., 1989, Encyklopedia katolicka, t. 2, Lublin.

LSjp - Linde S. B., 1854 (wyd. 2), Słownik języka polskiego, t. 1, Lwów.

15 Zob. np. Raszewska-Żurek (2010). Autorka zwraca uwagę na XVI-wieczne użycia wyrazu pies na nazwanie pogan, zwykle w odniesieniu do Turków i Tatarów. 
Nkpp - Krzyża nowski J., red., 1969-1972, Nowa księga przysłów i wyrażeń przysłowiowych polskich, t. 1-3, Warszawa.

SjpD - Doroszewski W., red., 1958, Słownik języka polskiego, t. 1, Warszawa.

SjpXVII - Słownik języka polskiego XVII i 1. połowy XVIII wieku, PAN (online: sxii.pl, dostęp: 17.07.2012.

SpXVI - Bąk S., Hrabec S. [et al.], red., 1967, Słownik polszczyzny XVI wieku, t. 2, Wrocław - Warszawa - Kraków (oraz materiały z kartoteki pracowni Słownika polszczyzny XVI wieku w Toruniu).

SsU - Urbańczyk S., red., 1953-1955, Słownik staropolski, t. 1, Warszawa.

Sw - Karłowicz J., Kryński A., Niedźwiecki W., red., 1900, Słownik języka polskiego, t. 1, Warszawa.

Swjp - Dunaj B., red., 1996, Słownik współczesnego języka polskiego, Warszawa.

BiałKat - Marcin Białobrzeski, 1566 [false; 1567], Katechizm albo Wizerunk prawej wiary chrześcijańskiej..., [Kraków: Łazarz Andrysowic].

BibRadz - Biblija święta, to jest księgi Starego i Nowego Zakonu..., 1563, Brześć: Druk. Radziwiłłowska.

BielKron - Marcin Bielski, 1564, Kronika, to jest historyja świata..., Kraków: Mateusz Siebeneicher.

BudBib - Szymon Budny, 1572, Biblija, to jest ksiegi Starego i Nowego Przymierza..., Nieśwież: Druk. Macieja Kawieczyńskiego, Daniel z Łęczycy.

BudNT - Szymon Budny, 1574, Nowy Testament..., Łosk: Daniel z Łęczycy.

CzechEp - Marcin Czechowic, [1583], Epistomium na Wędzidło Jego Miłości księdza Hieronima Powodowskiego..., [Kraków: Aleksy Rodecki].

CzechRozm - Marcin Czechowic, 1575, Rozmowy chrystyjańskie, które z greckiego nazwiska dialogami zowią..., [Kraków:] Aleksy Rodecki.

DolBitKontr - Matiasz Doliwski, 1641, Bitwa ministrów..., [w:] Z. Nowak, Kontrreformacyjna satyra w Polsce XVII wieku, Gdańsk 1968, s. 308-314.

KromRozm I - Marcin Kromer, 1551, O wierze i o nauce Luterskiej. Rozmowa dworzanina $z$ mnichem, Kraków: Łazarz Andrysowic.

KromRozm II - Marcin Kromer, 1552, Czego się krześcijański człowiek dzierżeć ma. Mnicha $z$ dworzaninem rozmowa wtóra, Kraków: Łazarz Andrysowic.

KrowObr - Marcin Krowicki, 1560, Obrona nauki prawdziwej i wiary starodawnej krześcijańskiej..., Pińczów: Daniel z Łęczycy.

NiemObr - Jan Niemojewski, 1583, Obrona przeciw niesprawiedliwemu obwinieniu i rozlicznym potwarzam, któremi ksiądz Powodowski [...] ludzi niewinnych w podejźrzenie i w brzydkie pohańbienie przywieść usiłuje..., [Kraków:] Aleksy Rodecki.

OrzQuin - Stanisław Orzechowski, 1564, Quincunx, to jest wzór Korony Polskiej..., [Kraków: Łazarz Andrysowic].

RejPos - Mikołaj Rej, 1566 (wyd. 3), Świętych słów a spraw pańskich, które tu sprawował Pan a Zbawiciel nasz [...] kronika albo postylla..., Kraków: Maciej Wirzbięta. 
RejZwierc - Mikołaj Rej, 1568, Źwierciadło albo kstałt, w którym każdy stan snadnie się może swym sprawam jako we źwierciadle przypatrzyć..., Kraków: Maciej Wirzbięta.

SkarJedn - Piotr Skarga, 1577, O jedności kościoła bożego pod jednym pasterzem..., Wilno: Druk. Radziwiłłowska.

SkarŻyw - Piotr Skarga, 1579, Żywotów świętych Starego i Nowego Zakonu z Pisma Świętego i z poważnych pisarzów i doktorów kościelnych wybranych część pierwsza..., Wilno: Druk. Radziwiłłowska.

StarKaz - Szymon Starowolski, 1649, Arka Testamentu zamykajaca w sobie kazania niedzielne..., cz. 2, Kraków: Druk. Krzysztofa Schedla.

\section{The symbolism of the noun baran ('ram') used to denominate people. The influence of religion on the development of the personified meaning of an appellative}

(Summary)

The paper describes the semantic changes of the meaning of the Polish appellative baran (ram) used to denote a person. The core meanings of the anthropomorphized noun in the sixteenth century were established on the basis of religious texts and related lay writings. The meanings were decidedly positive as they referred to Christ, Catholics, and, to a greater extent, to virtuous and righteous people. In the next centuries, the marking changed completely and the very noun baran was used as an insult and conveyed unequivocally negative values.

Parallel to the above study, a comparative analysis of the semantic evolution of the diminutive baranek (lamb), which could also function as personal designation, was conducted. In texts written in the Middle Polish language, the word functioned parallel to the root baran; however, in time, the distribution of both words diverged and their semantic evolution followed two completely different directions. The deminutivum did not undergo such a significant meaning amelioration as the noun baran. 